688
$8 / 17 / 72$

RFP-1876

July 14, 1972

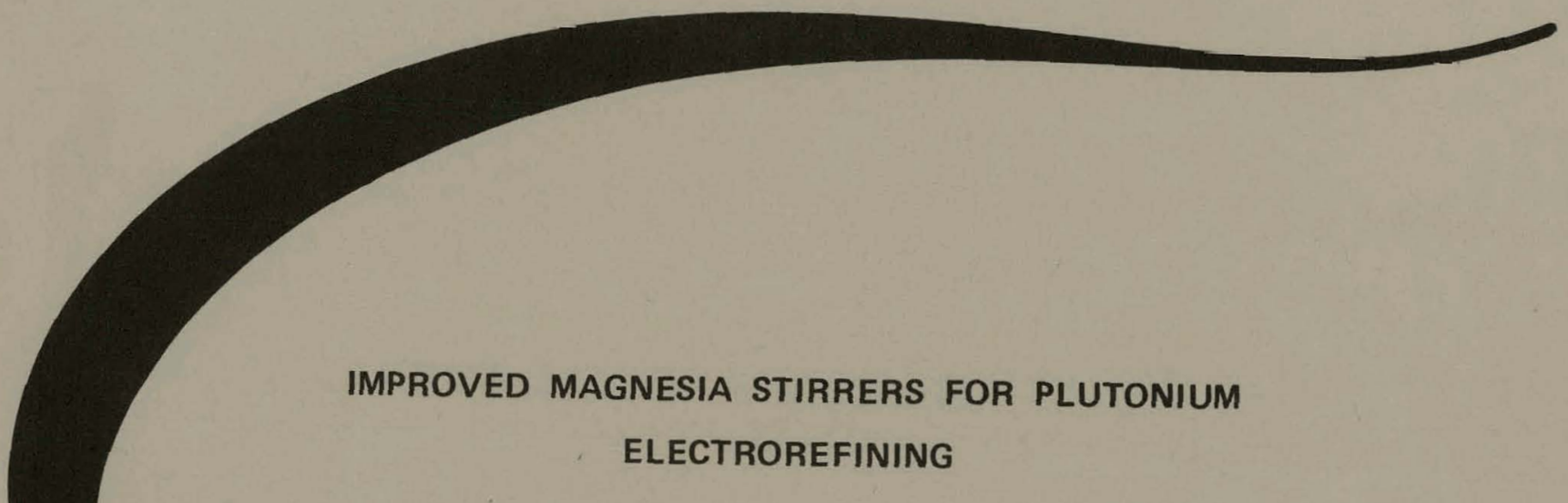

Carl J. Smith

Ronald L. Leggett

Alton R. Teter

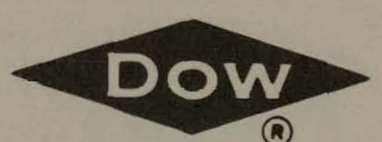

(2)

DOW CHEMICAL U.S.A. ROCKY FLATS DIVISION

P. O. BOX 888

GOLDEN, COLORADO 80401

U.S. ATOMIC ENERGY COMMISSION

CONTRACT AT(29-1)-1106 


\section{DISCLAIMER}

This report was prepared as an account of work sponsored by an agency of the United States Government. Neither the United States Government nor any agency Thereof, nor any of their employees, makes any warranty, express or implied, or assumes any legal liability or responsibility for the accuracy, completeness, or usefulness of any information, apparatus, product, or process disclosed, or represents that its use would not infringe privately owned rights. Reference herein to any specific commercial product, process, or service by trade name, trademark, manufacturer, or otherwise does not necessarily constitute or imply its endorsement, recommendation, or favoring by the United States Government or any agency thereof. The views and opinions of authors expressed herein do not necessarily state or reflect those of the United States Government or any agency thereof. 


\section{DISCLAIMER}

Portions of this document may be illegible in electronic image products. Images are produced from the best available original document. 


\section{LEGAL NOTICE}

This report was prepared as an account of work spunsured by the United States Government. Neither the United States nor the United States Atomic Energy Commission, nor any of thcir employees, nor any of their contractors, subcontractors, or their employees, makes any warranty, expressed or implied, or assumes any legal liability or responsibility for the accuracy, completeness or usefulness of any information, apparatus, product or process disclosed, or represents that its use would not infringe privately owned rights.

Printed in the United States of America

Available from the

National Technical Information Service

U. S. Department of Commerce

Springfield, Virginia 22151

Price: Printed Copy $\$ 3.00$; Microfiche $\$ 0.95$ 


\title{
IMPROVED MAGNESIA STIRRERS FOR PLUTONIUM ELECTROREFINING
}

\author{
Carl J. Smith
}

Ronald L. Leggett

Alton R. Teter

Research and Ecology

CERAMICS GROUP

\begin{abstract}
This report was prepared as an account of work sponsored by the United States Government. Ne.jther the United States nor the United States Atomic Energy Commission, nor any of their employees, nor any of their contractors; subcontractors, or their employees, makes any warrant $y$, express or implied, or assumes any legal liability or responsibility for the accuracy, completeness or usefulness of any information, apparatus, product or process disclosed, or represents that its use would not infringe privately owned rights.
woild
\end{abstract}

NOTICE

\author{
DOW CHEMICAL Ü.S.A. \\ ROCKY FLATS DIVISION \\ P. O. BOX 888 \\ GOLDEN, COLORADO 80401
}

Prepared under Contract AT(29-1)-1106

for the

- Albuquerque Operations Office

U. S. Atomic Energy Commission 


\section{CONTENTS}

Abstract $\ldots \ldots \ldots \ldots \ldots \ldots \ldots \ldots \ldots \ldots \ldots \ldots \ldots \ldots \ldots \ldots \ldots \ldots \ldots$

Introduction $\ldots \ldots \ldots \ldots \ldots \ldots \ldots \ldots \ldots$

Results and Discussion $\quad \ldots \ldots \ldots \ldots \ldots \ldots \ldots \ldots \ldots \ldots$

Summary $\ldots \ldots \ldots \ldots \ldots \ldots \ldots \ldots \ldots \ldots \ldots \ldots \ldots$ 


\title{
IMPROVED MAGNESIA STIRRERS FOR PLUTONIUM ELECTROREFINING
}

\author{
Carl J. Smith, Ronald L. Leggett, and Alton R. Teter
}

\begin{abstract}
During electrorefining processes, stirrers are used to agitate plutonium metal and the electrolyte. Stirrers in use must withstand conditions of high temperature, thermal shock, abrasion, and chemical attacks during 36-hour cycles. The major cause of magnesia stirrer failures used in electrorefining cells has been from effects of thermal shock. By closely controlling entry and withdrawal rates from the molten salt, stirrer longevity was increased considerably. Other failures caused by poor process control have been eliminated by improving concentricity, thickness, and increasing fired density.
\end{abstract}

Reported are details of a new stirrer design with better reliability for longer use and also available for lower stirring speeds which reduce seal and bearing failures.

\section{INTRODUCTION}

Magnesia stirrers used in plutonium electrorefining ${ }^{1}$ must withstand torque, thermal shock, abrasion, and chemical attack during a 36-hour cycle. Approximately 30 percent of the stirrers have been failing during the cycle. These failures have been attributed to thermal shock and in some cases to mechanical stress. Reduction in run failures are needed in electrorefining in order to obtain more favorable costs, as compared to wet chemical processing. The objective of the project was to develop a more reliable stirrer for longer and more efficient use in the electrorefining process.

The scope of the project was to:

1. Improve concentricity and uniformity of thickness of the stirrer so that it would be more resistant to thermal shock and mechanical stress during the stirring operation.

\footnotetext{
1 Jack L. Long and Robert D. Schwiekhardt. Plutonium Electrorefining at Rocky Flats. RFP-871. Rocky Flats Division, The Dow Chemical Company, Golden, Colorado. April 17, 1967.
}

2. Increase the fired density so that dye-penetrant tests could be used to check for surface defects prior to use.

3. Investigate the possibility of using a magnesiaalumina spinel stirrer, which has a higher mechanical strength.

4. Test thermal-shock resistance of stirrers in a mock electrorefining cell.

5. Evaluate the stirrers in actual electrorefining cycles.

A process was developed at Los Alamos Scientific Laboratory (LASL) in Los Alamos, New Mexico, for fabricating magnesia stirrers by solid-slip casting in $1960 .^{2}$ The slip-casting method was expensive and required careful processing techniques, which did not readily lend to production operations. A much improved and cheaper process utilizing isostatic pressing was developed at Rocky Flats in $1965 .^{3}$ The basic process developed has been used to fabricate the stirrers for the present investigation.

\section{RESULIS AND DISCUSSIÓN}

The arc-fused magnesia powders used for pressing the test stirrers were prepared by ball milling and spray drying. These powders contained 4.0 percent polyvinyl alcohol as a temporary binder and 3.0 percent yttrium oxide $\left(\mathrm{Y}_{2} \mathrm{O}_{3}\right)$ as a sintering aid. The prepared powders were vibrated into a stirrer mold and isostatically pressed at 20,000 pounds per square inch (psi). (For metric use: $1 \mathrm{psi}=$ 7 kilopascals; 1 inch $=25.4$ millimeters.)

Some of the stirrers which were failing had been pressed in a support container. The container did

\footnotetext{
${ }^{2}$ S. D. Stoddard, D. E. Nuckolls, and R. E. Cown. Preparation of Pure Impervious Magnesia by Aqueous Slip Casting. LAMS-2639. Los Alamos Scientific Laboratory, Los Alamos, New Mexico. 1961.

3A. R. Teter. Isostatically Pressed Magnesia Stirrers for Electrorefining Plutonium Metal. RFP-825. Rocky Flats Division, The Dow Chemical Company, Golden, Colorado. October 13, 1966.
} 


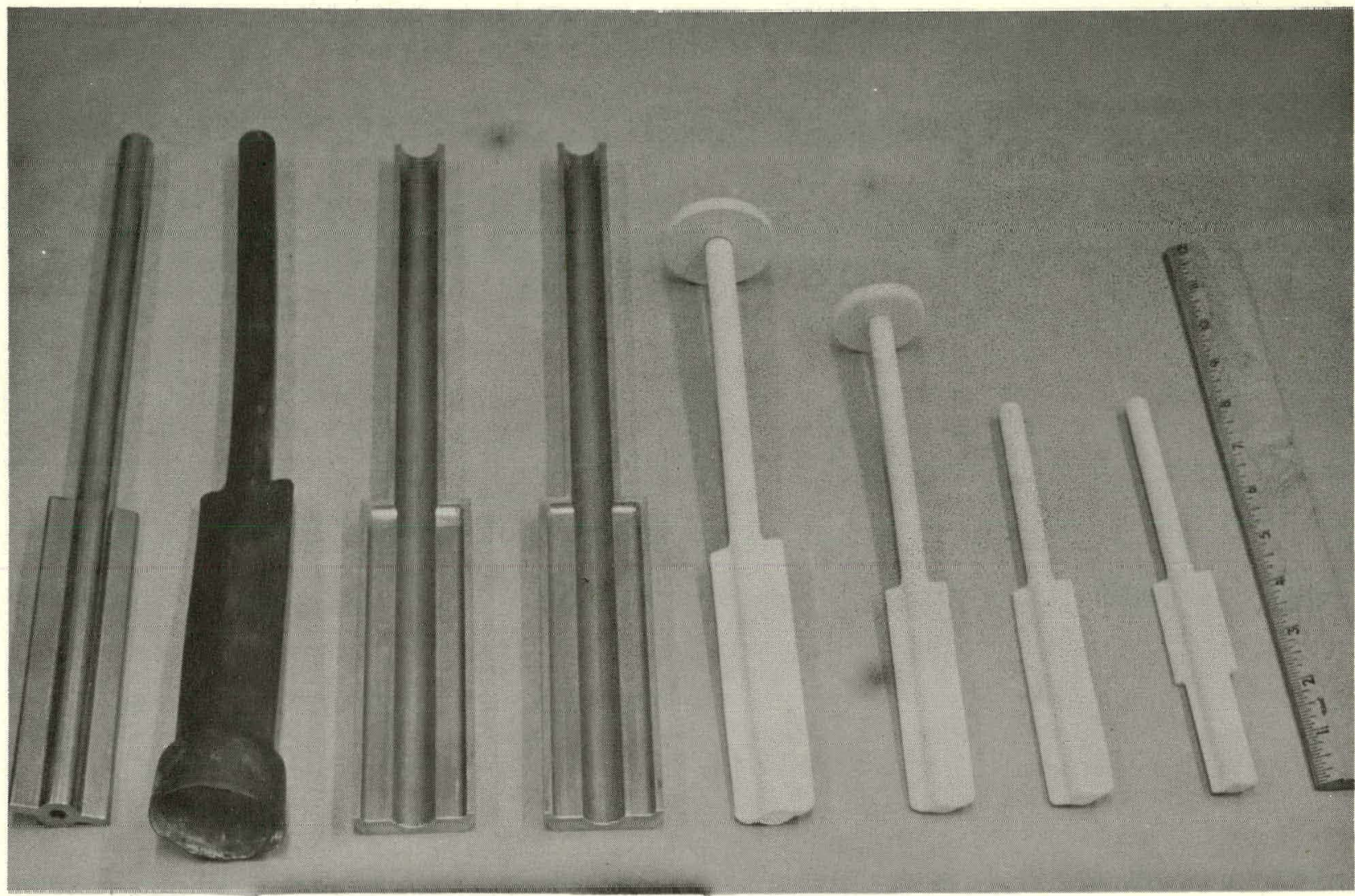

(a)

(b)

(c)

(d)

(e)

(f)

(g)

FIGURE 1. Tooling Used to Fabricate New Stirrer: Mold Model (a), Neoprene Mold (b), Support Cans (c), Pressed Stirrer (d), Sintered Stirrer (e), Stirrer Cut to Length (f), and Machined Stirrer (g).

not fit the neoprene pressing mold satisfactorily, and caused thickness variations and distortions to occur during pressing. A new precision-support container improved shaft straightness considerably and resulted in uniform thickness in the blade and shaft area. Figure 1 shows the tooling used for fabricating the improved paddle-shaped stirrer. The neoprene-pressing molds were dip-formed on the mold model. To fabricate the modified paddle stirrer, part of the web was machined away and helped to produce more stirring action in the lowdensity molten salt than in the high-density plutonium.

A process was developed for hang firing the stirrers to insure that only controlled distortion occurred during firing (see Figure 2). To prepare the stirrers for hang firing, a 2-inch diameter magnesia disk was slipped over the shaft, then a fired pin inserted in a hole in the shaft to hold the disk in place. The stirrers were then inserted into alumina tubes for firing at $1730^{\circ} \mathrm{C}$ for 8 hours. Some of the magnesia stirrers produced by this technique were unsatisfactory because of a reaction with the alumina support tube.

The process was further improved by suspending the stirrers between rows of alumina bricks during firing (see Figure 3). Using this technique, the stirrers could be better aligned prior to firing and the rigid supports were less subject to distortion during the firing cycle. 


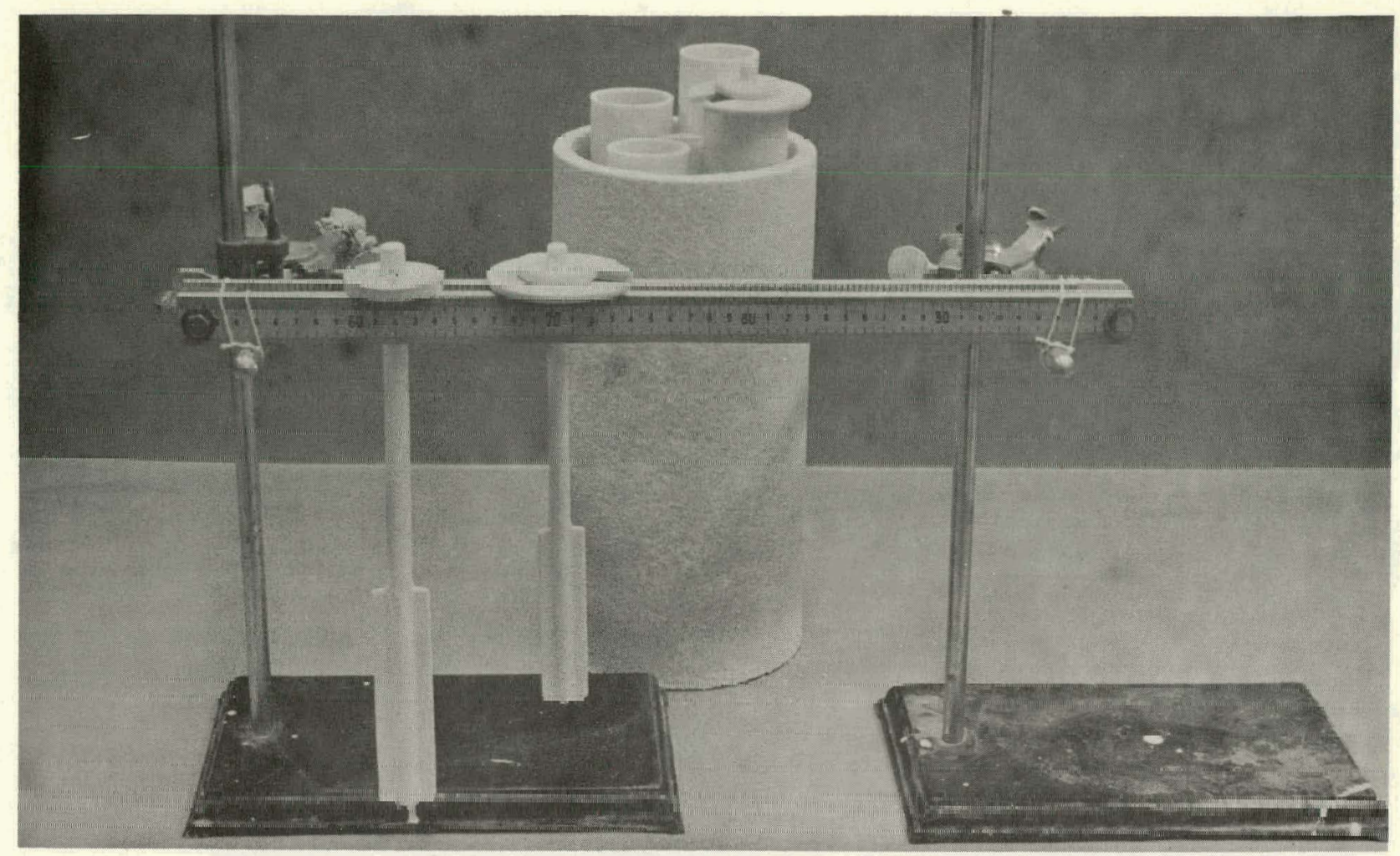

FIGURE 2. Initial Configuration for Hang Firing of Magnesia Stirrers.

15231-5

FIGURE 3. Final Configuration for Hang Firing of Stirrers.

$15396-11$

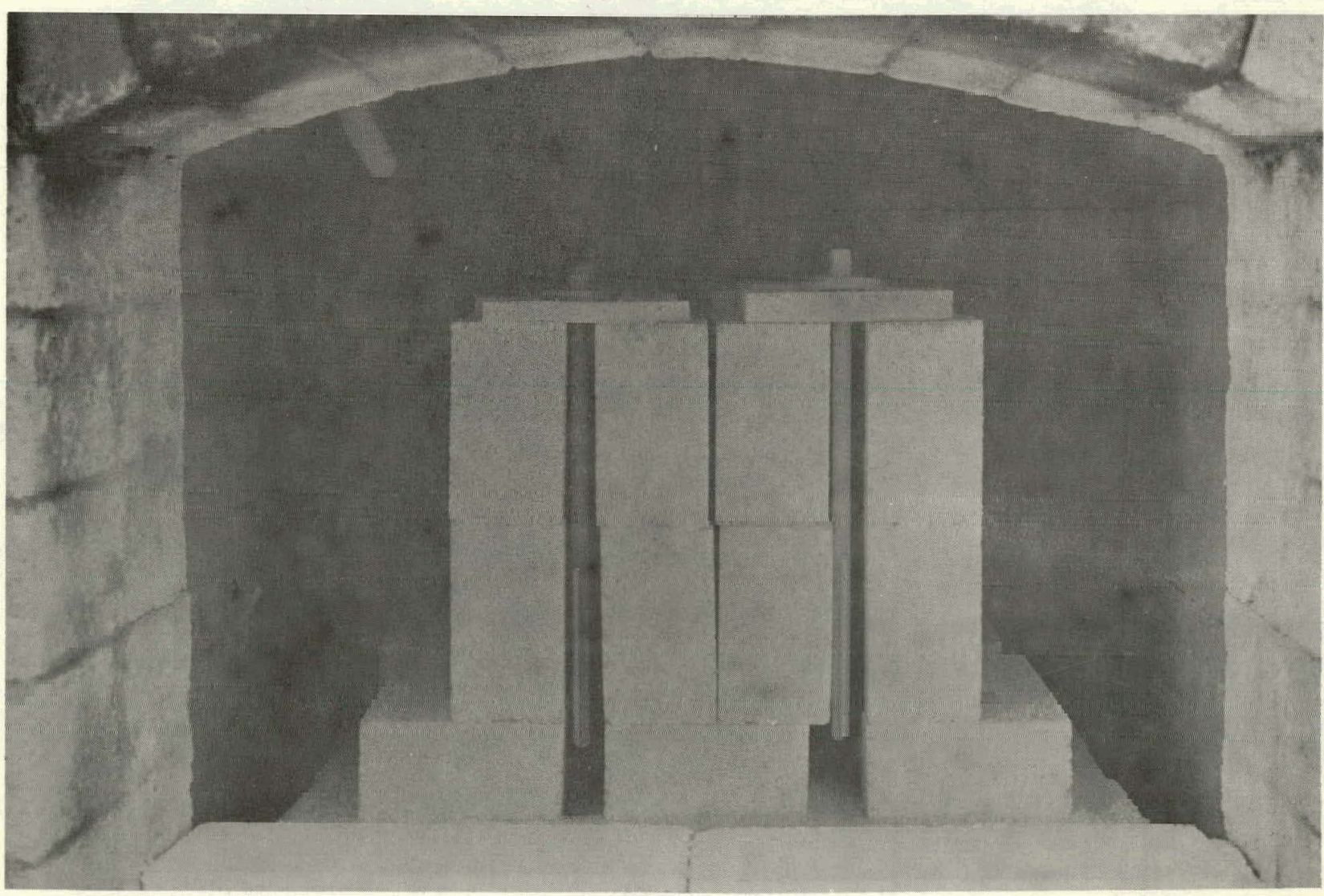




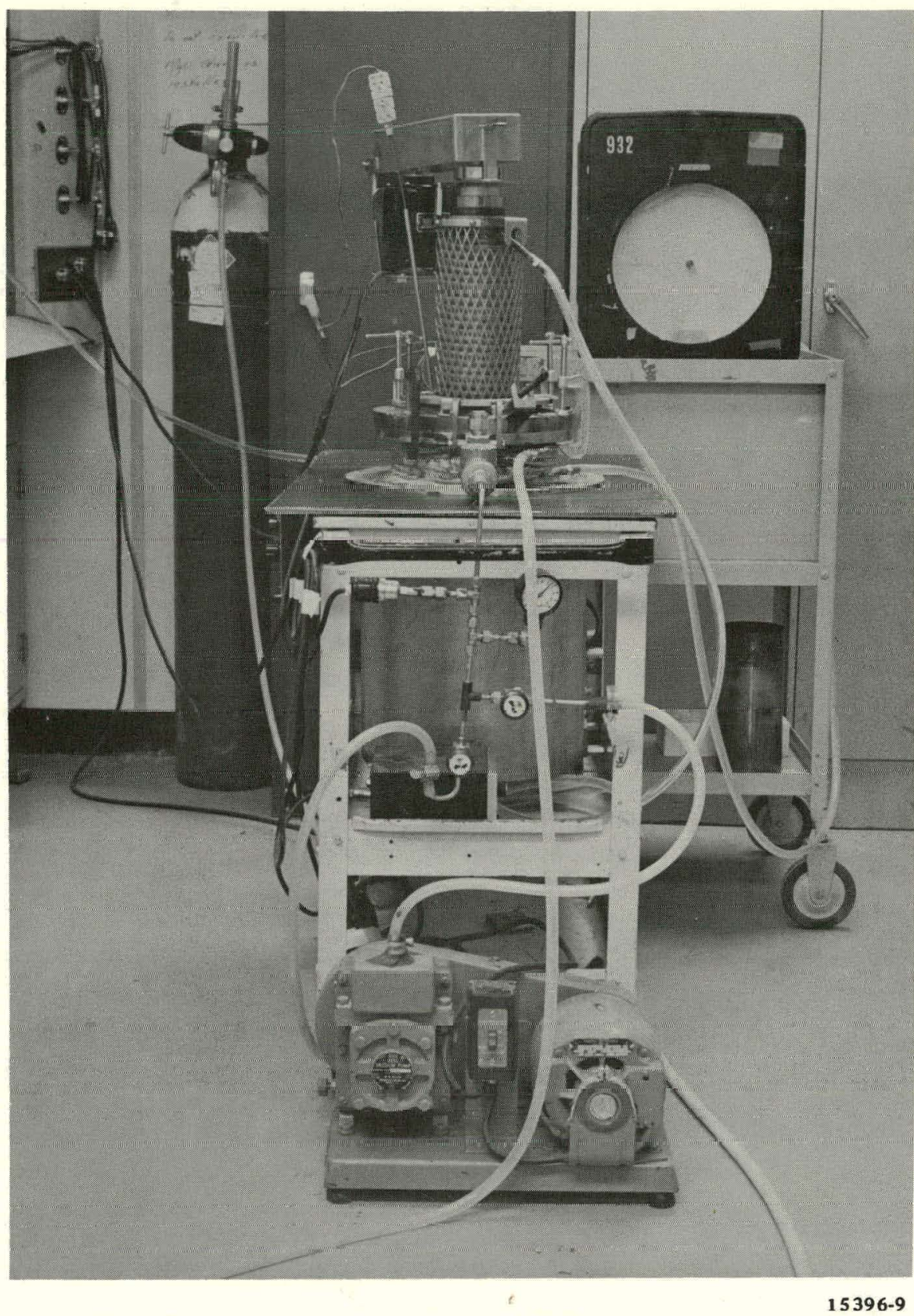

FIGURE 4. Electrorefining Cell Used for Evaluating Thermal-Shock Resistance of Magnesia Stirrers.

Four different milling times were used to produce finer particle-size distributions which would result in increased sintered densities. The increased densities were accompanied by plastic deformation which, incidently, further straightened the stirrers during hang firing. The sintered properties for the stirrers are given in Table I. The bulk density (percent of theoretical) was increased from 92.5 to 99.0 percent by increasing the milling time 12 hours. Plastic deformation occurred only in stirrers attaining greater than 97.5 percent of theoretical density.

In addition, stirrers attaining greater than $\mathbf{9 7 . 5}$ percent of theoretical density could be checked for surface cracks and high porosity areas by dyepenetration tests. This made it possible to eliminate stirrers containing undesirable areas prior to use in 
TARI.F. I Sintered Properties of Magnesia Stirrers Sintered at $1730^{\circ} \mathrm{C}$ for Eight Hours.

\begin{tabular}{|c|c|c|c|c|}
\hline $\begin{array}{l}\text { Mill Time } \\
\text { (hours) } \\
\end{array}$ & $\begin{array}{l}\text { Particle Size } \\
\text { (micrometers) }\end{array}$ & $\begin{array}{c}\text { Percent } \\
\text { Theoretical } \\
\text { Density } \\
\end{array}$ & $\begin{array}{c}\text { Percent } \\
\text { Firing } \\
\text { Shrinkage } \\
\end{array}$ & $\begin{array}{l}\text { Results of Hang } \\
\text { Firing }\end{array}$ \\
\hline 48 & 0.5 to 12 & 92.5 & 14.0 & No plasticity \\
\hline 50 & 0.4 to 10 & 94.8 & 15.3 & No plasticity \\
\hline 54 & 0.3 to 8 & 97.5 & 17.4 & Plasticity \\
\hline 60 & 0.3 to 7 & 99.0 & 17.9 & Plasticity \\
\hline
\end{tabular}

electrorefining. The increased sintered densities should also improve the chemical-corrosion resistance of the stirrers.

An electrorefining unit (for nonradioactive materials) was constructed to evaluate the magnesia stirrers during simulated electrorefining runs (see Figure 4). The salt charge was increased to duplicate the volume of plutonium used in actual electrorefining cycles. Thirty-cight cycles were completed with no failures occurring as a result of mechanical stress or chemical corrusion. These tests ranged from 5 to 36 hours in duration with the same stirrers being used an average of 4 cycles. The tests did indicate that the stirrers would fail as a result of thermal gradients if they were immersed or extracted from the molten salt too rapidly.

Tests were conducted to determine the minimum times required for introducing the sliness into the molten salt. Sitrrers immersed into the salt at a rate of 2 inches per minute failed during the first cycle. Stirrers entered at a rate of 1 inch per minute failed after an average of 2.6 cycles. At an immersion rate of 0.5 inches per minute, nine stirrers were tested through a total of 87 cycles with no failures due to thermal shock.

Spinel stirrers were evaluated by immersing them al a rate of 0.5 inches per minutc. Three out of five failed in less than 3 cycles. No further tests were conducted on the spinel stirrers since they had such poor thermal-shock resistance.

Nine magnesia stirrers were evaluated in plutonium electrorefining runs. The stirrers included 3 of the LASL type and 3 each of 2 different Dow designs (see Figure 5). All 9 test cycles produced excellent high-purity plutonium yields with no stirrer

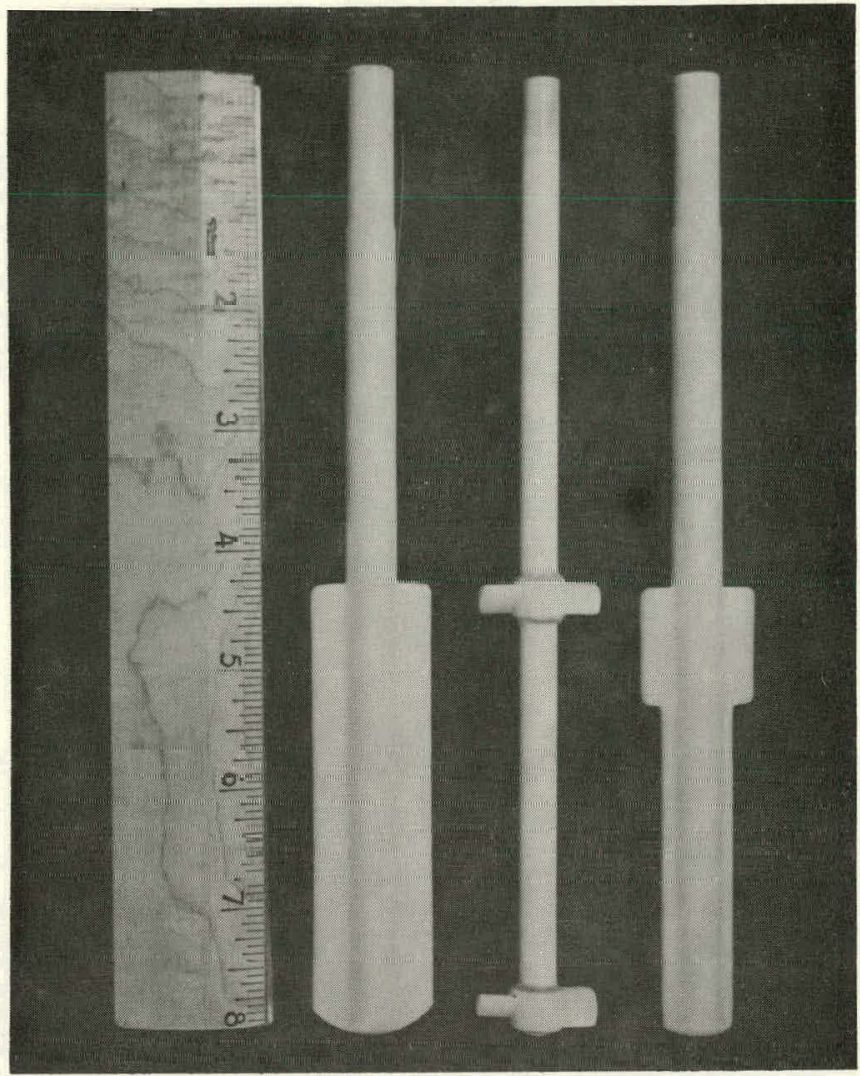

(a)

(b)

(c)

FIGURE 5. Stirrer Types Evaluated: the Dow Paddle (a), the Los Alamos Scientific Laboratory Stirrer (b), and a Modified Dow Paddle (c).

failures. The Dow stirrers produced the same stirring action at approximately one-third of the revolutions per minute (rpm) required for the LASL stirrers. The lower rpm required for the Dow stirrers should reduce the chances of bearing and seal failures during operation.

\section{SUMMARY}

Precision molds and hang firing have improved the quality of magnesia stirrers. Increased sintered densities have also made it possible to detect surface imperfections in the stirrers prior to use. The most tangible improvement in eliminating stirrer failures, however, relates to the use of stirrer entry and removal rates of 0.5 inches per minute or less. 